\title{
IIICET
}

Volume 3 Nomor 2, 2018, hlm 107-113

DOI: https://doi.org/10.29210/300327900

ISSN: 2502-079X (Print)

ISSN: 2503-1619 (Electronic)

Info Artikel:

Diterima: $15 / 11 / 2018$

Direvisi: 23/12/2018

Dipublikasikan: 27/12/2018

Dipublikasikan oleh:

Indonesian Institute for Counseling, Education and Therapy (IICET)

Akses Online :

http://jurnal.iicet.org/index.php/jrti

\section{Peningkatan kemampuan motorik halus melalui bermain playdough di taman kanak-kanak qur'aniah air runding pasaman barat}

\author{
Isnani Sari ${ }^{1}$, Rakimahwati ${ }^{2}$ \\ ${ }^{12}$ Universitas Negeri Padang \\ e-mail: isnanisari08@gmail.com
}

\begin{abstract}
This study aims to improve children's fine motor skills through playing playdough in Qur'aniah Air Runding Pasaman Barat. The type of research is Classroom Action Research conducted in a cyclical way that is two cycles of each cycle three meetings. which was held in Qur'aniah Air Runding Child B group with 15 children consisting of 8 men and 7 women. The research procedure is done as much as II cycle. Data collection techniques used observation and documentation techniques. Based on the results of the research, it can be seen that playdough can improve the fine motor skills of children in Qur'aniah Air Runding Pasaman West, with the percentage of the average value of the category developed very well that has reached the Minimum Criterion (KKM).
\end{abstract}

Keywords: Fine motoric, Playdough

\section{PENDAHULUAN}

Pendidikan sangat penting dalam kehidupan (Mustari \& Rahman, 2011; Sudrajat, 2011) dan pandidikan merupakan modal dasar untuk menyiapkan diri menjadi orang yang berkualitas untuk memenuhi kebutuhan perkembangan dan sekaligus memenuhi tuntutan sosial, cultural, dan religious (Nugraha \& Rachmawati, 2014). Anak-anak adalah generasi penerus bangsa, kesadaran akan arti 
penting generasi penerus yang berkualitas mengharuskan kita serius membekali anak dengan pendidikan yang baik agar menjadi generasi yang lebih baik dari pendahulunya, pendidikan dimulai sejak anak usia dini (Rakimahwati, Lestari, \& Hartati, 2018)

Peraturan Menteri Pendidikan dan Kebudayaan Republik Indonesia No. 137 tahun 2014 pasal 1 butir 10 (Pendidikan \& Nomor, 2013), Pendidikan Anak Usia Dini merupakan suatu upaya pembinaan yang ditujukan kepada anak sejak lahir sampai dengan usia 6 tahun yang dilakukan melalui pemberian rancangan pendidikan untuk membantu pertumbuhan dan perkembangan jasmani dan rohani agar anak memiliki kesiapan dalam memasuki pendidikan lebih lanjut (Permono, 2013).

Pendidikan usia dini merupakan wahana pendidikan yang sangat penting dalam memberikan kerangka dasar terbentuk dan berkembang dasar-dasar pengetahuan, sikap dan keterampilan anak (Ahmad Susanto, 2016). Program pendidikan harus mampu memberikan bekal yang tinggi dan tangguh. Keberhasilan penyelenggaraan pendidikan dalam lembaga pendidikan anak usia dini seperti: Kelompok Bermain (KB), Taman Kanak-kanak (TK) sangat bergantung pada sistem dan proses pendidikan selanjutnya (Ali, 2009).

Penyelenggaraan pendidikan anak usia dini merupakan upaya pembinaan yang ditujukan bagi anak sejak lahir sampai dengan usia delapan tahun sesuai dengan tahap tahap perkembangan yang dilalui oleh anak usia dini yang dilakukan melalui pemberian rangsangan pendidikan untuk membantu pertumbuhan dan perkembangan jasmani dan rohani agar anak memiliki kesiapan dalam memasuki pendidikan lebih lanjut. Dengan upaya program pembinaan yang terencana dan sistematis diharapkan anak mampu mengembangkan potensi yang dimiliki secara optimal (Ahmad Susanto, 2016)

Anak usia dini adalah individu yang sedang mengalami proses pertumbuhan dan perkembangan yang pesat bahkan dikatakan sebagai lompatan perkembangan karena itu usia dini dikatakan sebagai usia emas (golden age) yaitu usia yang berharga dibanding usia selanjutnya (Mufidah, 2013). Usia tersebut merupakan fase kehidupan yang unik dengan karakteristik khas, baik secara fisik, psikis, sosial dan moral. Anak pada usia dini memiliki kemampuan belajar luar biasa khususnya pada masa awal kanak-kanak (Rakimahwati, R, 2014; Rakimahwati, R, 2017).. Keinginan anak untuk belajar menjadikan anak aktif dan eksploratif (Zaman, 2014). Anak belajar dengan seluruh panca inderanya untuk memahami sesuatu dan dalam waktu singkat anak beralih ke hal lain untuk dipelajari.

Berk dalam Yulsyofriend (2013) menyatakan bahwa Anak usia dini adalah sosok individu yang sedang menjalani suatu proses perkembangan dengan pesat dan fundamental bagi kehidupan selanjutnya. Anak Usia Dini berada pada rentangan usia 0-8 tahun. Proses pertumbuhan dan perkembangan dalam berbagai aspek sedang mengalami masa yang cepat dalam rentang perkembangan hidup manusia (Sumantri, 2014). Proses pembelajaran sebagai bentuk perilaku yang diberikan pada anak harus memperhatikan karakteristik yang dimiliki setiap tahapan perkembangan anak.

Aspek-aspek perkembangan dan kemampuan anak usia dini terdiri dari perkembangan kemampuan fisik, kognitif, bahasa, sosial, agama dan moral serta seni. Pada masa ini proses pertumbuhan dan perkembangan dalam berbagai aspek sedang mengalami masa yang cepat dalam rentang perkembangan hidup manusia. Salah satu aspek yang perlu distimulasi di Taman Kanakkanak adalah aspek fisik motorik. Alasan utama aspek motorik menjadi bagian dari sasaran Taman Kanak-kanak karena perkembangan motorik memiliki hubungan yang sangat erat dengan aspek-aspek yang lain. Apabila motorik seorang anak bagus, maka bisa dengan mudah dan lancar melakukan suatu kegiatan atau aktivitas yang menunjang pertumbuhan dan perkembangannya.

Perkembangan motorik terbagi dua yaitu: motorik kasar dan motorik halus. Motorik kasar adalah gerakan/aktivitas yang menggunakan otot-otot besar atau bahkan seluruh anggota tubuh. Motorik halus adalah kemampuan yang berhubungan dengan keterampilan fisik yang melibatkan otot-otot kecil. Pengembangan motorik halus dapat dilakukan melalui berbagai kegiatan dalam bermain (Rakimahwati, R, 2014; Rakimahwati, R, 2018). 
Kegiatan bermain tersebut seperti kegiatan pelatihan yang dilakukan didalam dan diluar ruangan atau dialam terbuka yang nyaman dan menyenangkan. Bentuk kegiatannya berupa stimulasi dan persiapan untuk perkembangan motorik halus anak melalui kegiatan seperti menggunting, menggambar, menganyam, melukis, meronce, menyusun balok-balok dan lain-lain. Melalui kegiatan ini diharapkan anak dapat mengembangkan motorik halusnya untuk persiapan menulis ataupun kegiatan yang berhubungan dengan motorik halus anak.

Menurut Jamaris (2003) motorik halus adalah kemampuan untuk beraktivitas menggerakkan otototot halus yang mengkoordinasikan gerakan jari tangan dan mata yang membutuhkan kecermatan yang terdapat dalam kegiatan meremas, memasang dan membuka kancing baju, meronce manik-manik, melipat kertas, menyusun balok dan melukis dengan jari.

Berdasarkan observasi awal di Taman Kanak-kanak Qur'aniah Air Runding didapatkan bahwa motorik halus anak belum berkembang secara optimal, anak sulit memegang gunting, anak belum mampu menggambar, rendahnya kemampuan anak dalam kegiatan mencetak dan melepaskan hasil cetakan, rendahnya kemampuan anak dalam kegiatan menggenggam. Kurang maksimalnya perkembangan motorik halus anak di kelas B Taman Kanak-kanak Qur'aniah Air Runding disebabkan oleh, kurangnya kemampuan guru dalam mengelola kegiatan, metode pembelajaran yang diberikan guru kurang bervariasi, media yang disediakan guru kurang menarik bagi anak, karena selama ini guru sering tergantung pada kegiatan yang ada di majalah bulanan seperti menggunting pola yang tersedia di majalah, menghubungkan titik-titik serta mewarnai majalah.

Playdough merupakan adonan mainan yang terbuat dari tepung. Alat permainan ini aman untuk anak dan dapat mengembangkan seluruh aspek perkembangan anak usia dini. Membuat playdough dapat melatih motorik halus anak usia dini. Anak-anak dapat menggunakan tangan dan peralatan untuk membentuk adonan, melalui pengalaman tersebut, anank-anak dapat mengembangkan koordinasi mata, tangan dan ketangkasan serta kekuatan tangan yang dapat menstimulasi perkembangan motorik anak untuk menulis dan mewarnai.

Menurut Jatmika (2012) playdough adalah adonan mainan atau yang merupakan bentuk modern dari mainan tanah liat (lempung) yang terbuat dari campuran tepung terigu. Playdough mudah dimainkan dan disukai oleh anak-anak. Playdough merupakan salah satu media pembelajaran yang murah, karena bahan untuk membuat playdough mudah didapatkan.

\section{METODOLOGI PENELITIAN}

Jenis Penelitian yang digunakan pada penelitian ini adalah metode Penelitian Tindakan kelas (PTK) atau Classroom Action Research (CAR). Penelitian ini dilaksanakan pada semester I tahun pelajaran 2018/2019 selama + 2 bulan. Penelitian ini dilaksanakan di Taman Kanak-kanak Qur'aniah Air Runding Pasaman Barat.Subjek Penelitian adalah anak kelompok B dengan jumlah 15 orang anak terdiri dari 8 orang anak laki-laki dan 7 orang anak perempuan. Data yang dikumpulkan melalui format observasi dan dokumentasi dan diolah melalui persentase.

\section{HASIL}

Berdasarkan penelitian yang telah peneliti lakukan, dimana menurut peneliti dari masing-masing siklus didapatkan bahwa melalui bermain playdoughdapat meningkatkan kemampuan motorik halus anak di Taman Kanak-kanak Qur'aniah Air Runding Pasaman Barat, berkembangnya kemampuan motorik halus anak dalam bermain playdough pada masing-masing aspek dengan kriterian ketuntasan maksimum (KKM) sebesar 75\%, hal ini terlihat dari tingkat perkembangan anak dari masing-masing siklus yang terus meningkat.

Untuk lebih jelasnya analisis data peningkatan kemampuan motorik halus melalui bermain playdough dengan nilai berkembang sangat baik dapat dijabarkan sebagai berikut: 
Tabel . Persentase Hasil Observasi Peningkatan Kemampuan Motorik Halus Anak Melalui Bermain playdough Dengan Nilai Berkembang Sangat Baik

\begin{tabular}{clccc}
\hline No & \multicolumn{1}{c}{ Aspek yang dinilai } & Siklus I & Siklus II & Ket \\
\hline 1 & $\begin{array}{l}\text { Anak mampu meremas adonan playdough melalui } \\
\text { bermain playdough }\end{array}$ & $40 \%$ & $87 \%$ & Meningkat \\
2 & $\begin{array}{l}\text { Anak mampu mencetak adonan playdough melalui } \\
\text { bermain playdough } \\
\text { Anak mampu melepaskan adonan dari cetakan } \\
\text { melalui bermain playdough }\end{array}$ & $40 \%$ & $80 \%$ & Meningkat \\
\hline
\end{tabular}

Berdasarkan tabel di atas dapat dilihat peningkatan kemampuan motorik halus melalui bermain playdough dengan nilai berkembang sangat baik pada masing-masing indikator.

Pada siklus I nilai berkembang sangat baik pada aspek pertama anak mampu meremas adonan playdough melalui bermain playdough berjumlah 6 orang dengan persentase $40 \%$ dan meningkat pada siklus II menjadi 13 orang dengan persentase $87 \%$. Pada aspek kedua anak mampu mencetak adonan playdough berjumlah 6 orang dengan persentase $40 \%$ dan meningkat pada siklus II menjadi 12 orang dengan persentase $80 \%$. Pada aspek ketiga anak mampu melepaskan adonan dari cetakan berjumlah 4orang dengan persentase $27 \%$ dan meningkat menjadi 12 orang dengan persentase $80 \%$. Untuk lebih jelasnya dapat dilihat pada grafik di bawah ini:

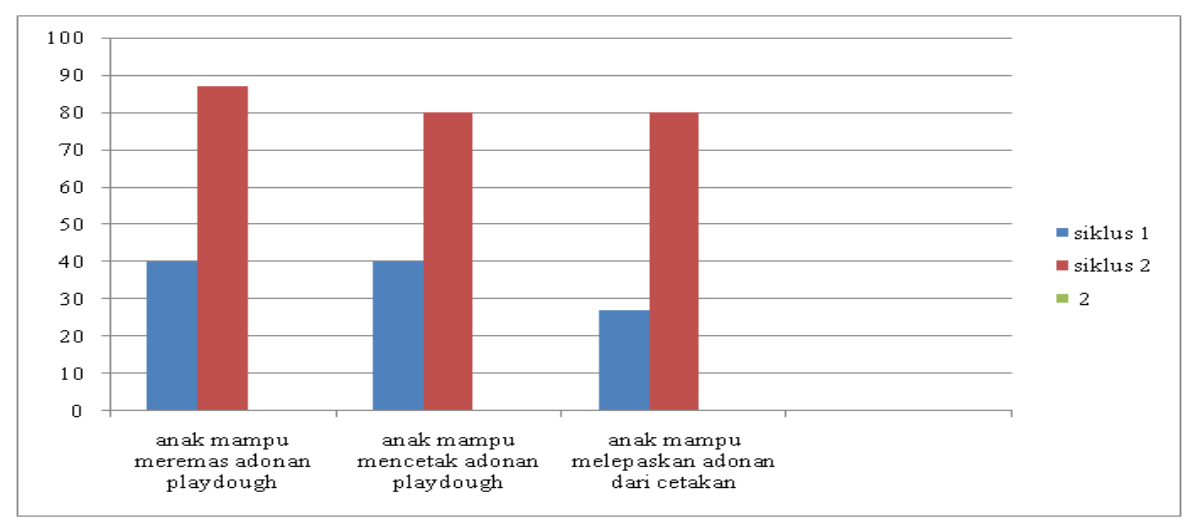

Gambar 1 Persentase Hasil Observasi Peningkatan Kemampuan Motorik Halus Anak Melalui Bermain playdough Dengan Nilai Berkembang Sangat Baik

Berdasarkan grafik di atas dapat disimpulkan bahwa terjadinya peningkatan pada penilaian anak kategori berkembang sangat baik dalam tiga indikator yang telah dilaksanakan pada siklus I dan siklus II. Pada aspek pertama dengan grafik warna biru $40 \%$, grafik warna merah meningkat menjadi $87 \%$. Aspek kedua dengan grafik warna biru $40 \%$, grafik warna merah meningkat menjadi $80 \%$. Aspek ketiga grafik warna biru $40 \%$, grafik warna merah meningkat $80 \%$.

\section{PEMBAHASAN}

Berdasarkan hasil penelitian peningkatan kemampuan motorik halus anak melalui bermain playdough di Taman Kanak-kanak qur'aniah Air Runding Pasaman Barat, adapun pembahasan guna untuk memperjelas dan memperdalam kajian penelitian ini, setelah melihat kondisi awal tentang kemampuan motorik halus anak di Taman Kanak-kanak qur'aniah Air Runding Pasaman Barat, peneliti melakukan penelitian tindakan kelas untuk memperbaiki kemampuan motorik halus anak melalui bermain playdough. 
Kegiatan bermain playdough ini adalah suatu kegiatan yang dapat merangsang perkembangan motorik halus anak. Dalam bermain anak merasakan kesenangan, kenikmatan dan kebebasan tersendiri salah satunya dengan bermain playdough. Seperti yang dikatakan Solehuddin dalam Suryana (2013) bermain adalah suatu kegiatan yang menyenangkan. Jadi dapat disimpulkan bahwa dalam kegiatan bermain merupakan kegiatan yang menyenangkan dan mengasyikkan bagi anak pada kegiatan bermain playdough.

Berdasarkan hasil analisis data yang didapatkan pada perkembangan aspek pertama anak mampu meremas adonan playdough melalui bermain playdough juga terjadi peningkatan pada setiap aspek pertemuan yang dilakukan.Melalui kegiatan meremas kemampuan motorik halus anak dapat ditingkatkan karena anak meremas-remaskan jari-jari tangannya supaya adonan menjadi rata.Dari kegiatan tersebut terjadi pengembangan motorik halus anak.Sesuai dengan pernyataan menurut Rakimahwati (2012) menjelaskan pengembangan motorik halus anak ditekankan pada koordinasi gerakan motorik halus, dalam hal ini berkaitan dengan kegiatan meletakkan atau memenag suatu objek dengan menggunakan jari tangan.

Berdasarkan teori di atas bahwa motorik halus anak berkaitan dengan meletakkan atau memegang suatu objek.Pada aspek kedua anak mampu meremas adonan playdough melalui bermain playdough terjadi pengembangan motorik halus karena kegiatan meremas itu anak memegang objek dan meletakkan objek itu kembali sehingga kegiatan tersebut anak menggunakan jari-jari tangannya untuk memegang dan meletakkan suatu objek.

Aspek kedua anak mampu mencetak adonan playdough dan pada aspek ketiga anak mampu melepaskan adonan dari cetakan melalui bermain playdough.Kedua aspek tersebut diperlukan ketelitian dalam melakukan kegiatan tersebut.Dengan adanya kegiatan mencetak dan melepas perkembangan motorik halus anak dapat berkembang, karena anak menggunakan jari-jarinya dan anak juga memerlukan ketelitian dalam mencetak dan melepas adonan dari cetakan. Zulkifli (2006) menjelaskan bahwa perkembangan motorik halus anak adalah perkembangan pengendalian gerakan jasmani melalui kegiatan pusat syaraf, urat syaraf dan otot yang terkoordinasi.Jadi, perkembangan motorik halus anak juga berkaitan dengan pusat syaraf anak.Pasa aspek kedua dan ketiga sangat diperlukan ketelitian anak dalam melakukan kegiatan, sehingga anak memerlukan konsentrasi dalam melakukan kegiatan mencetak dan melepas playdough dari cetakan.Dari aspek anak mampu mencetak adonan playdough dan melepas adonan playdough dari cetakan melalui bermain playdough, kegiatan ini mampu untuk mengembangkan motorik halus anak.

Bermain playdough ini merupakan salah satu dari sekian banyak cara untuk meningkatkan kemampuan motorik halus dengan upaya agar anak mampu meremas adonan playdough melalui bermain playdough, anak mampu mencetak adonan playdough melaui bermain playdough dan anak mampu melepas adonan dari cetakan melalui bermain playdough. Secara sederhana penelitian ini telah berhasil dilakukan dalam peningkatan kemampuan motorik halus anak.

\section{SIMPULAN DAN SARAN}

Berdasarkan hasil penelitian dan pembahasan yang telah di uraikan di atas untuk meningkatkan kemampuan motorik halus melalui bermain playdough maka dapat disimpulkan sebagai berikut: Peningkatan motorik halus pada anak merupakan suatu kegiatan yang terpadu, yang tercakup beberapa kegiatan yaitu, meremas adonan playdough, mencetak adonan playdough dan melepas adonan dari cetakan melalui bermain playdough.Hasil yang diperoleh mengenai peningkatan kemampuan motorik halus anak pada masing-masing indikator yang telah ditetapkan maka anak yang mendapat nilai berkembang sangat baik pada kondisi awal 0\%, sedangkan pada siklus I mengalami kenaikan 36\% dan mengalami kenaikan yang sangat bagus pada siklus II menjadi $82 \%$. Ini menandakan bahwa dengan bermain playdough dapat meningkatkan kemampuan motorik halus.Sedangkan pada penilaian Belum Berkembang pada masing-masing indikator yang telah ditetapkan dimana pada kondisi awal $80 \%$ mendapat nilai belum berkembang, pada akhir siklus I mengalami penurunan menjadi $25 \%$ dan anak yang mendapat nilai belum berkembang pada akhir siklus II $0 \%$.Hal ini menandakan dengan pendekatan yang rutin dan sungguh-sungguh disertai motivasi yang diberikan guru untuk lebih 
meningkatkan kemampuan motorik halus anak sangat berpengaruh terhadap kemampuan motorik halus anak sehingga anak meningkat kemampuannya.

Berdasarkan simpulan di atas, ada beberapa saran yang ingin peneliti uraikan demi kesempurnaan penelitian tindakan kelas dimasa yang akan datang diantaranya: Kepala Sekolah sebaiknya menyediakan alat-alat permainan yang dapat meningkatkan kemampuan motorik halus anak. Bagi Guru hendaknya menggunakan media pembelajaran salah satunya dengan bermain playdough untuk meningkatkan kemampuan motorik halus anak, dengan begitu anak tidak akan merasa jenuh dalam belajar serta tujuan pembelajaran akan tercapai secara maksimal. Bagi anak Taman Kanak-kanak Qur'aniah Air Runding diharapkan dapat mengikuti pembelajaran dengan baik sehingga proses pembelajaran dapat berjalan dengan efektif.Diharapkan kepada Dinas terkait untuk memberikan perhatian yang besar dalam peningkatan kemampuan motorik halus anak di Taman Kanak-kanak Qur'aniah Air Runding Pasaman Barat pada khususnya dan Kecamatan Koto Balingka pada umumnya.Bagi masyarakat diharapkan dapat menggunakan skripsi ini sebagai sumber ilmu pengetahuan guna menambah wawasan.

\section{DAFTAR RUJUKAN}

Ahmad Susanto, M. P. (2016). Teori belajar dan pembelajaran di sekolah dasar. Kencana.

Arikunto, Suharsimi. (2007). Penelitian Tindakan Kelas. Jakarta: Bumi Aksara.

Ali, M. (2009). Pendidikan untuk pembangunan nasional: menuju bangsa Indonesia yang mandiri dan berdaya saing tinggi. Grasindo.

Fitri, E., Zola, N., \& Ifdil, I. (2018). Profil Kepercayaan Diri Remaja serta Faktor-Faktor yang

Mempengaruhi. JPPI (Jurnal Penelitian Pendidikan Indonesia), 4(1), 1-5.

Jamaris, Martini.2003. Perkembangan Anak Usia TK. Jakarta: UNJ

Jatmika, Yusep Nur. 2012. Ragam Aktivitas Harian untuk Play Group. Yogyakarta: Diva Pres.

Mufidah, U. (2013). Efektivitas Pemberian Reward Melalui Metode Token Ekonomi Untuk Meningkatan Kedisiplinan Anak Usia Dini. Universitas Negeri Semarang.

Mustari, M., \& Rahman, M. T. (2011). Nilai karakter: refleksi untuk pendidikan karakter. Laksbang Pressindo.

Nugraha, A., \& Rachmawati, Y. (2014). Metode Pengembangan Sosial.

Pendidikan, P. M., \& Nomor, K. R. I. (2013). 137 Tahun 2014. Standar Nasional Pendidikan Anak Usia Dini.

Peraturan Menteri Pendidikan dan Kebudayaan Republik Indonesia No. 137 tahun 2014 tentang Standar Nasional Pendidikan Anak Usia Dini.

Permono, H. (2013). Peran orangtua dalam optimalisasi tumbuh kembang anak untuk membangun karakter anak usia dini.

Rakimahwati, R. (2018). Pelatihan Pembuatan Boneka Jari Bergambar dalam Meningkatkan Kemampuan Membaca Anak Usia Dini di Kecamatan V Koto Kampung dalam Kabupaten Padang Pariaman. Early Childhood: Jurnal Pendidikan, 2(2b), 1-11.

Rakimahwati, R. (2017). Interactive Game Influences Based on Inquiry Learning Model Towards The Ability of Reading in Kindergarten in Padang. In International Conference of Early Childhood Education (ICECE 2017). Atlantis Press.

Rakimahwati, R. (2014). Character Development through Dance Learning in an Early Childhood Setting. Indonesian Journal of Early Childhood Education Studies, 3(2), 102-107.

Rakimahwati, R. (2014). The Effectiveness of a Crossword Puzzle Game in Improving Numeracy Ability of Kindergarten Children. Asian Social Science, 10(5), 79.

Rakimahwati, (2012) Model Pembelajaran Sambil Bermain pada Pendidikan Anak Usia Dini. Padang: UNP Press.

Rakimahwati, R., Lestari, N. A., \& Hartati, S. (2018). Pengaruh Kirigami Terhadap Kemampuan Motorik Halus Anak di Taman Kanak-Kanak. Jurnal Obsesi: Jurnal Pendidikan Anak Usia Dini, 2(1), 102-110.

Reski, N., Taufik, T., \& Ifdil, I. (2017). Konsep diri dan kedisiplinan belajar siswa. Jurnal 
EDUCATIO: Jurnal Pendidikan Indonesia, 3(2), 85-91.

Sudrajat, A. (2011). Mengapa Pendidikan Karakter? Jurnal Pendidikan Karakter, 1(1).

Sumantri, M. (2014). Perkembangan peserta didik.

Suryana, Dadan. 2013. Pendidikan Anak Usia Dini (Teori dan Praktik Pembelajaran. Padang: UNP Press.

Yulsyofriend. 2013. Permainan Membaca dan Menulis Anak Usia Dini. Padang: Sukadina Press.

Zaman, B. (2014). Media dan Sumber Belajar TK.

Zulkifli. (2006). Psikologi Perkembangan. Bandung: PT Remaja Rosdakarya 